\title{
Taxonomy and bioecology of Hemiptera Diaspididae in fruit and landscape trees
}

\author{
Jurabek Yakhyoev ${ }^{1, *}$, Khojimurod Kimsanbayev $^{2}$, Bakojon Murodov $^{2}$, and Zukhra \\ Akmedova $^{1}$ \\ ${ }^{1}$ Institute of Zoology, Uzbek Academy of Sciences, Bogishamol str., 232b, Tashkent, Uzbekistan \\ ${ }^{2}$ Tashkent State Agrarian University, University str., 2, Tashkent province, Uzbekistan, 100140
}

\begin{abstract}
Scales damage many plants such as apples, pears, plums, quinces, peaches, almonds, hawthorn, pine, poplar and other orchards and ornamental trees. According to the taxonomic composition of the fauna of scales found in fruit and ornamental plants of Tashkent province in Uzbekistan, the number of generations in the family Diaspididae in the fauna is 18 (Diaspidiotus, Diaspis, Dynaspidiotus, Unaspis, Shansiaspis, Salicicola, Parlatoria, Lepidosapis, Lepidosaphes, Lepidosaphes, Lepidosaphes Carulaspis, Rhizaspidiotus, and Pseudaulacaspis), and the number of species was 30. Diaspidiotus (8 species, 26.6\%) and Lepidosaphes (4 species, 13.3\%) predominate in the distribution of species, while Diaspis, Dynaspidiotus, Unaspis, Shansiaspis, Salicicola, Parlatoria, Leucaspis, Aulacaspis, Aonidia, and Chon. The number of species of the genus Chlidaspis, Prodiaspis, Mercetaspis, Carulaspis and Rhizaspidiotus is monotypic, the representatives of the genus Parlatoria and Chionaspis have 2 species and account for $13.3 \%$ of the total fauna. Aonidia, Chlidaspis, Prodiaspis, Mercetaspis, Carulaspis and Rhizaspidiotus genus have 1 species, accounting for $46.7 \%$ of the total fauna.
\end{abstract}

\section{Introduction}

Today, the cultivation and supply of fruits and vegetables to the population is one of the most important priorities of agriculture in the world [1,12]. At the same time, the fact that the negative impact of pests and diseases on crops increases to $35-40 \%$, indicates the need to further improve the system of combating them. In particular, scales, which are serious pests of fruit and ornamental plants, cost the agricultural and horticultural sector $\$ 5$ billion a year [2,16]. Accordingly, the identification of harmful diaspid species in fruit and ornamental trees, the development of measures to combat them is of great scientific and practical importance [2].

In the world today, special attention is paid to diaspidological research, the study of the faunal composition of different regions by modern methods, the study of their origin on the basis of the evolution of scales. Work has been developed on the faunistic composition, biology, ecology, taxonomic composition, trophic relationships and phylogeny of

\footnotetext{
* Corresponding author: jurabek.yakhyoyev@yandex.com
} 
diaspidofauna of ecological zones in different regions [3, 10, 14]. It should be noted that research is needed to identify the fauna of scales in fruit and ornamental plants, their morpho-ecological properties, biological characteristics of some common species, adaptation to living in food plants and the use of integrated control methods [4, 7]. In this regard, further development of scientific research, including the identification of species diversity of scales, assessment of the impact of pests on trees and shrubs, the study of the distribution, biology and ecological characteristics of the most serious species, is of great scientific and practical importance[4, 13-15].

In Uzbekistan, along with various sectors of agriculture, great attention is paid to the full satisfaction of the needs of the population in fruit and vegetable products through the development of horticulture on the basis of state programs. In this regard, in particular, new intensive gardens have been established and a number of measures have been taken to increase productivity [5-7]. The Action Strategy for the further development of the Republic of Uzbekistan sets tasks to further strengthen the country's food security, expand the production of environmentally friendly products, and significantly increase the export potential of the agricultural sector. In carrying out these tasks, scientific and practical research aimed at identifying the fauna of scales and their seasonal dynamics, including the improvement of coordinated protection measures against them, plays an important role [68].

Today, the world's leading countries pay special attention to the study of the bioecology of orchard pests, which play an important role in the sustainable development of the agricultural complex and food security. Here, especially in the orchards of Uzbekistan, California scale (Diaspidiotus perniciosus Comst) pests for almost all species and widespread fruit trees are mainly apples, pears, plums, cherries, peaches, cherries, apricots, as well as black currants, hawthorn, rose, willow, flowers, red-fruited shrubs cause serious damage to plants (Figure 1) [9, 10, 16].
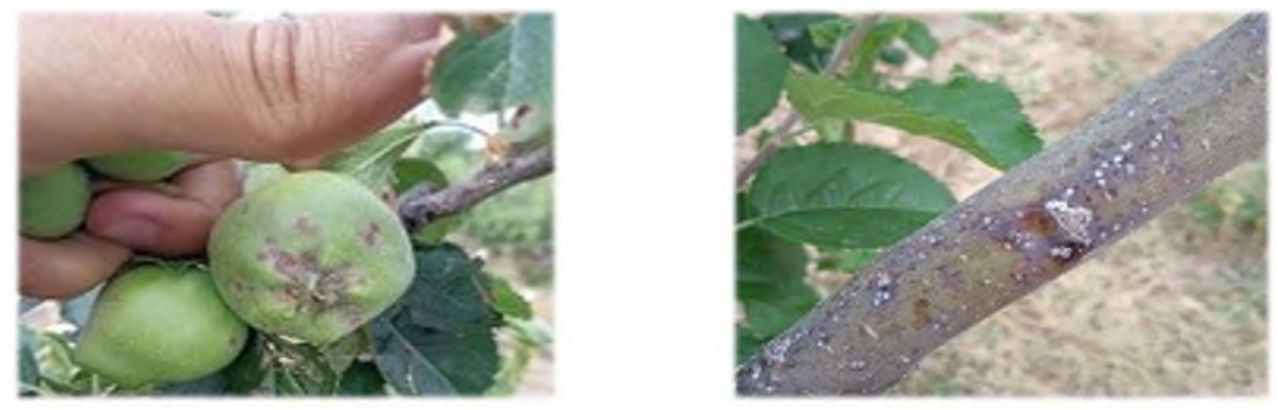

Fig. 1. Damaged apple fruit and stem by Diaspidiotus perniciosus Comst.

EPPO code on the basis of the European and Mediterranean Plant Protection Organization of California scale, European and International Plant Protection Organization (EPPO/EOKZR): Registered under QUADPE, Aonidiella perniciosa, Aspidiotus perniciosus, Diaspidiotus perniciosus, Quadraspidiotus perniciosus, and Comstockaspis perniciosa has been learned and studied by scientists [6-9].

\section{Materials and methods}

The research was conducted in Tashkent province, Institute of Zoology of the Academy of Sciences of the Republic of Uzbekistan, Laboratory of Entomophagous Ecology and Theoretical Foundations of Biosteres, Department of Plant Protection of Tashkent State 
Agrarian University and the State Inspectorate for Plant Quarantine under the Cabinet of Ministers.

Samples of scales belonging to 18 genera in the Diaspididae family were collected from different developmental stages of the total identified species. Specimens of these insects in the offspring are as follows: Diaspidiotus (8), Diaspis (1), Dynaspidiotus (1), Unaspis (1), Shansiaspis (1), Salicicola (1), Parlatoria (2), Lepidosaphes (4), Leucaspis (1), Aulacaspis (1), Aonidia (2), Chlidaspis (1), Prodiaspis (1), Mercetaspis (1), Carulaspis (1), Rhizaspidiotus (1), and Pseudaulacaspis (1).

Some of these materials are stored in the collection of the Department of Entomology of the Institute of Zoology of the Academy of Sciences of the Republic of Uzbekistan. The main materials were collected from different biotopes of Tashkent province in 2018-2020. The study of scales was carried out during individual and complex faunal expeditions. More fruit and ornamental trees in the study include: Salix alba L, Salix nigra Mar, Salix babylonica L, Euonymus japonica Thunb, Ficus benjamina L, Rosa canina L, Cydonia oblonga Mill, Malus domestica Borkh, Pistacia vera L, and Pistacia mutica L, and in identifying scales distributed in varieties such as Prunus domestica L, the lower, middle, and upper tiers of the plant were examined to determine which scales are currently overwintering and at which stage of development in the food plant. Collection and storage of accumulated scales was carried out on the basis of the methodology by NS Borxsenius $[6,12]$. The materials of the collection were stored in separate boxes; the specimens on the leaves were kept in a herbarium, while the scales were cut from 10-15 cm long branches of the forage plant.

The study of the biological properties of scales began in the spring and was systematically monitored at weekly intervals. Observations were performed using the bioassay method (once a day) on selected model trees based on the order of scales in the plant body, branches and twigs, as well as the order of scales in fruits and leaves. In addition, when taking samples from scales, an attempt was made to take the trees on the circular sides of parts of the same height from the ground. Variation in the number of scales in the module trees, the life processes of laying eggs, the emergence of larvae, the emergence of males were also studied.

In the laboratory, samples taken from the twigs of forage plants in nature were placed in beakers of water. In addition to the vital processes in the branches, it is possible to observe the duration of the vital processes of scales. We have seen that the life of twigs stored in water containers can last a month or two. Naturally, during these months there will be an opportunity to study the biological properties of scales in the branches. This was done by photographing the egg laying of scales under natural conditions and counting the eggs laid. The fertility of the females located on the branch was determined as follows. As the scale of the scales on the rod was raised, the number of eggs laid under the scale was counted using magnifiers. The fertility of scales was determined and processed in the laboratory using a stereoscope binocular, and statistical and zoogeographic analysis was performed. The morphological and classification characteristics of scales have been studied on the basis of a number of identifiers and scientific sources relevant to the field.

The study of the biological properties of scales took into account, first of all, the period of their wintering, the emergence of larvae from eggs in spring, the gradual transition of larvae from the first to the second year, skin shedding, young females or males. In addition, larvae of male insects were isolated and stored in test tubes, and the time of emergence of males in the laboratory was determined. Also, under MBS-9 binoculars, the processes of female egg laying and larval emergence from eggs were constantly monitored. The development of scales found in selected and selected tree trunks was monitored on a regular basis (Tashkent province and Tashkent city). 
Samples from plants infested with scales were cut, labeled, and studied in the laboratory. Samples taken during the field observations were numbered and recorded in a notebook. During sampling from different ecological zones, 10 control plants were selected from all four sides of the area, and 10 samples were taken from them. The trees under control were conditionally divided into three tiers, and the placement of scales along the tiers was determined. The control focused on the number of tufts, the age and composition of the populations. The length of the horns taken from the samples was $10 \mathrm{~cm}$. Some of the samples (bark, twigs, leaves, and fruits) were cut and placed in a special box lined with cotton wool, and some were soaked in $70 \%$ alcohol and fixed in the laboratory to study the species composition.

Morphological characteristics and morphometric dimensions of scales were monitored in the laboratory under a magnifying glass and MBS-9 binocular microscope. In the process of collecting material, the age of the offspring of scale individuals was also clarified. The research was conducted in an artificially organized environment as well as in natural conditions. In the laboratory, studies of the embryonic development of scales have been conducted on species that have been artificially adapted to live in individual plants.

Permanent field observations on biological and ecological properties of scales were conducted in Tashkent province and Tashkent, and practical laboratory observations were conducted at the Institute of Zoology of the Academy of Sciences of Uzbekistan, Laboratory of Entomophagous Ecology and the Department of Plant Protection of Tashkent State Agrarian University.

\section{Results and discussion}

The fauna and taxonomic analysis of scales found in fruit and ornamental trees of Tashkent province were studied. The following are the results of taxonomic analysis of scales found in fruit and ornamental plants of Tashkent province (Table 1).

Table 1. Taxonomic list of scales found in fruit and ornamental plants of Tashkent province

\begin{tabular}{|c|c|c|c|c|}
\hline \multirow{3}{*}{\multicolumn{2}{|c|}{ \# }} & Group & Hemiptera & \\
\hline & & Family & Diaspididae & \\
\hline & & Latin name & English name & Synonym \\
\hline \multicolumn{3}{|r|}{ Generation } & Diaspidiotus & \\
\hline 1 & 1 & $\begin{array}{c}\text { Diaspidiotus } \\
\text { perniciosus } \\
\text { (Comstock, 1881) } \\
\end{array}$ & California scale & $\begin{array}{l}\text { Quadraspidiotus } \\
\text { perniciosus }\end{array}$ \\
\hline 2 & 2 & $\begin{array}{l}\text { Diaspidiotus elaeagni } \\
\text { (Borchsenius, 1939) }\end{array}$ & Armoured scale & Aspidiotus elaeagni \\
\hline 3 & 3 & $\begin{array}{l}\text { Diaspidiotus salicis } \\
\text { (Lupo, 1953) }\end{array}$ & Poplar scale & Quadraspidiotus salicis \\
\hline 4 & 4 & $\begin{array}{c}\text { Diaspidiotus } \\
\text { transcaspiensis } \\
\text { (Marlatt, 1908) } \\
\end{array}$ & Caspian scale & $\begin{array}{l}\text { Hendaspidiotus } \\
\text { transcaspiensis }\end{array}$ \\
\hline 5 & 5 & $\begin{array}{c}\text { Diaspidiotus } \\
\text { slavonicus } \\
\text { (Green, 1934) }\end{array}$ & Poplar bubble scale & $\underline{\text { Targionia slavonica }}$ \\
\hline 6 & 6 & $\begin{array}{c}\text { Diaspidiotus } \\
\text { prunorum } \\
\text { (Laing, 1931) } \\
\end{array}$ & Turon scale & Diaspidiotus prunorum \\
\hline 7 & 7 & $\begin{array}{l}\text { Diaspidiotus turanicus } \\
\text { (Borchsenius, 1935) }\end{array}$ & Willow scale & Aspidiotus turanicus \\
\hline 8 & 8 & Diaspidiotus & Legume scale & Aspidiotus leguminosum \\
\hline
\end{tabular}




\begin{tabular}{|c|c|c|c|c|}
\hline & & $\begin{array}{c}\text { leguminosum } \\
\text { (Archangelskaya, } \\
\text { 1937) }\end{array}$ & & \\
\hline \multicolumn{3}{|r|}{ Generation } & Diaspis & \\
\hline 9 & 1 & $\begin{array}{c}\text { Diaspis bromeliae } \\
\text { (Kerner, 1778) }\end{array}$ & Pineapple scale & $\underline{\text { Coccus bromeliae }}$ \\
\hline \multicolumn{3}{|r|}{ Generation } & Dynaspidiotus & \\
\hline 10 & 1 & $\begin{array}{c}\text { Dynaspidiotus } \\
\text { ephedrarum } \\
\text { (Lindinger, 1912) }\end{array}$ & Ephedrium scale & Aspidiotus ephedrarum \\
\hline \multicolumn{3}{|r|}{ Generation } & Unaspis & \\
\hline 11 & 1 & $\begin{array}{l}\text { Unaspis euonymi } \\
\text { (Comstock, 1881) }\end{array}$ & Euonymus scale & Unaspis evonymi \\
\hline \multicolumn{3}{|r|}{ Generation } & Shansiaspis & \\
\hline 12 & 1 & $\begin{array}{c}\text { Shansiaspis ovalis } \\
\text { (Chen, 1983) }\end{array}$ & Tamarix scale & Chionaspis engeddensis \\
\hline \multicolumn{3}{|r|}{ Generation } & Salicicola & \\
\hline 13 & 1 & $\begin{array}{c}\text { Salicicola } \\
\text { archangelskyae } \\
\text { (Lindinger, 1929) } \\
\end{array}$ & Pear scale & $\begin{array}{c}\frac{\text { Leucaspis }}{\text { archangelskyae }} \\
\underline{4}\end{array}$ \\
\hline \multicolumn{3}{|r|}{ Generation } & Parlatoria & \\
\hline 14 & 1 & $\begin{array}{c}\text { Parlatoria oleae } \\
\text { (Colvée, 1880) }\end{array}$ & Purple scale & Diaspis oleae \\
\hline 15 & 2 & $\begin{array}{l}\text { Parlatoria ephedrae } \\
\text { (Lindinger, 1911) }\end{array}$ & $\begin{array}{l}\text { Ephedrium pear-shaped } \\
\text { scale }\end{array}$ & Parlatorea ephedrae \\
\hline \multicolumn{3}{|r|}{ Generation } & Lepidosaphes & \\
\hline 16 & 1 & $\begin{array}{c}\text { Lepidosaphes turanica } \\
\text { (Archangelskaya, } \\
\text { 1937) }\end{array}$ & Mealybug & Mytilaspis turanica \\
\hline 17 & 2 & $\begin{array}{l}\text { Lepidosaphes juniperi } \\
\text { (Lindinger, 1912) }\end{array}$ & Juniper mealybug & Insulaspis juniperi \\
\hline 18 & 3 & $\begin{array}{l}\text { Lepidosaphes ulmi } \\
\text { (Linnaeus, 1758) }\end{array}$ & Apple mealybug & $\underline{\text { Coccus ulmi }}$ \\
\hline 19 & 4 & $\begin{array}{c}\text { Lepidosaphes } \\
\text { pistaciae } \\
\text { (Archangelskaya, } \\
\text { 1930) }\end{array}$ & Pistachio mealybug & Pistaciaspis pistaciae \\
\hline \multicolumn{3}{|r|}{ Generation } & Leucaspis & \\
\hline 20 & 1 & $\begin{array}{l}\text { Leucaspis gigas } \\
\text { (Maskell, 1879) } \\
\end{array}$ & Giant armoured scale & $\underline{\text { Diaspis gigas }}$ \\
\hline \multicolumn{3}{|r|}{ Generation } & Aulacaspis & \\
\hline 21 & 1 & $\begin{array}{l}\text { Aulacaspis rosarum } \\
\text { (Borchsenius, 1958) }\end{array}$ & Rose scale & Aulacaspis thoracica \\
\hline \multicolumn{3}{|r|}{ Generation } & Aonidia & \\
\hline 22 & 1 & $\begin{array}{c}\text { Aonidia isfarensis } \\
\text { (Borchsenius, 1962) }\end{array}$ & Isphara scale & Cupressaspis isfarensis \\
\hline \multicolumn{3}{|r|}{ Generation } & Chionaspis & \\
\hline 23 & 1 & $\begin{array}{c}\text { Chionaspis salicis } \\
\text { (Linnaeus, 1758) }\end{array}$ & Willow bubble scale & $\underline{\text { Coccus salicis }}$ \\
\hline 24 & 2 & $\begin{array}{c}\text { Chionaspis etrusca } \\
\text { (Leonardi, 1908) }\end{array}$ & Tamarix scale & Chionaspis engeddensis \\
\hline \multicolumn{3}{|r|}{ Generation } & Chlidaspis & \\
\hline 25 & 1 & $\begin{array}{c}\text { Chlidaspis asiatica } \\
\text { (Archangelskaya, } \\
1930 \text { ) }\end{array}$ & Central Asian plum scale & Chionaspis asiatica \\
\hline
\end{tabular}




\begin{tabular}{|c|c|c|c|c|}
\hline \multicolumn{3}{|r|}{ Generation } & \multirow[b]{2}{*}{ White tamarix scale } & \multirow[b]{2}{*}{$\frac{\frac{\text { Adiscodiaspis }}{\text { tamaricicola }}}{\underline{\text { tam }}}$} \\
\hline 26 & 1 & $\begin{array}{c}\text { Prodiaspis } \\
\text { tamaricicola } \\
\text { (Malenotti, 1916) }\end{array}$ & & \\
\hline \multicolumn{3}{|r|}{ Generation } & Mercetaspis & \\
\hline 27 & 1 & $\begin{array}{c}\text { Mercetaspis halli } \\
\text { (Green, 1923) }\end{array}$ & Hall scale & Nilotaspis halli \\
\hline \multicolumn{3}{|r|}{ Generation } & Carulaspis & \\
\hline 28 & 1 & $\begin{array}{l}\text { Carulaspis juniper } \\
\text { (Bouché, 1851) }\end{array}$ & Juniper pest & Diaspis juniperi \\
\hline \multicolumn{3}{|r|}{ Generation } & Rhizaspidiotus & \\
\hline 29 & 1 & $\begin{array}{c}\text { Rhizaspidiotus } \\
\text { canariensis } \\
\text { (Lindinger, 1911) }\end{array}$ & Canary grass scale & Aspidiotus canariensis \\
\hline \multicolumn{3}{|r|}{ Generation } & Pseudaulacaspis & \\
\hline 30 & 1 & $\begin{array}{c}\text { Pseudaulacaspis } \\
\text { pentagona } \\
\text { (Targioni Tozzetti, } \\
1886 \text { ) }\end{array}$ & Plum scale & Diaspis pentagona \\
\hline
\end{tabular}

As can be seen from the table, according to the taxonomic composition of the fauna of scales found in fruit and ornamental plants of Tashkent province, the number of generations in the family Diaspididae in the fauna is 18 (Diaspidiotus, Diaspis, Dynaspidiotus, Unaspis, Shansiasipis, Saliciaspis, Salicicala, Parlator, Parlator Prodiaspis, Mercetaspis, Carulaspis, Rhizaspidiotus and Pseudaulacaspis), and the number of species is 30.

The distribution of scales in the fauna by families was studied. Diaspidiotus ( 8 species, 26.6\%) and Lepidosaphes (4 species, 13.3\%) predominate in the distribution of species, while Diaspis, Dynaspidiotus, Unaspis, Shansiaspis, Salicicola, Parlatoria, Leucaspis, Aulacaspis, Aonidia, Chon. It can be seen that the number of species of the genus Chlidaspis, Prodiaspis, Mercetaspis, Carulaspis and Rhizaspidiotus is of a monotypic nature (Table 2).

Table 2. Generation and species ratio of scales of Tashkent province

\begin{tabular}{|c|c|c|}
\hline$\#$ & Generations & $\begin{array}{c}\text { Number of species in the fauna and their } \\
\text { ratio (\%) }\end{array}$ \\
\hline 1 & Diaspidiotus & $8(26.6 \%)$ \\
\hline 2 & Diaspis & $1(33.3 \%)$ \\
\hline 3 & Dynaspidiotus & $1(33.3 \%)$ \\
\hline 4 & Unaspis & $1(33.3 \%)$ \\
\hline 5 & Shansiaspis & $1(33.3 \%)$ \\
\hline 6 & Salicicola & $1(33.3 \%)$ \\
\hline 7 & Parlatoria & $2(6.67 \%)$ \\
\hline 8 & Lepidosaphes & $4(13.3 \%)$ \\
\hline 9 & Leucaspis & $1(33.3 \%)$ \\
\hline 10 & Aulacaspis & $1(33.3 \%)$ \\
\hline 11 & Aonidia & $1(33.3 \%)$ \\
\hline 12 & Chionaspis & $2(6.67 \%)$ \\
\hline 13 & Chlidaspis & $1(33.3 \%)$ \\
\hline 14 & Prodiaspis & $1(33.3 \%)$ \\
\hline 15 & Mercetaspis & $1(33.3 \%)$ \\
\hline 16 & Carulaspis & $1(33.3 \%)$ \\
\hline 17 & Rhizaspidiotus & $1(33.3 \%)$ \\
\hline 18 & Pseudaulacaspis & $1(33.3 \%)$ \\
\hline & Total & $30(100,0 \%)$ \\
\hline
\end{tabular}


Parlatoria and Chionaspis genus has 2 species, accounting for $13.3 \%$ of the total fauna, while the remaining genera, namely Diaspis, Dynaspidiotus, Unaspis, Shansiaspis, Salicicola, Leucaspis, Aulacaspis, Aonidia, Chlidaspis, Prodiaspis, Rdiaspis, and Merc representatives of the genus had 1 species, accounting for $46.7 \%$ of the total fauna.

Among the identified species, Diaspidiotus transcaspiensis (Marlatt, 1908), Diaspis bromeliae (Kerner, 1778), Dynaspidiotus ephedrarum (Lindinger, 1912), and Parlatoria ephedrae (Lindinger, 1911) were recorded for the first time for the diaspidofauna of Tashkent province.

During the observations in 2018-2020, the species of scales on fruit trees in Tashkent province were identified, including very dangerous species. These include the California scale (Diaspidiotus perniciosus Comst), the purple scale (Parlatoria oleae Colvee), the apple scale (Lepidosaphes ulmi Lin), the plum scale (Tecaspis asiatica Arch), and the rose scale (Aulacaspis rosae Bouche) were studied.

In apple orchards, purple scale and California scale have the highest level of damage to various shrubs, i.e. $34.4 \%$ purple scale, $30.2 \%$ California scale, $11.4 \%$ plum scale, $10.9 \%$ apple comma scale, $8.9 \%$ rose scale, while the remaining species accounted for $6.9 \%$ (Figure 2).

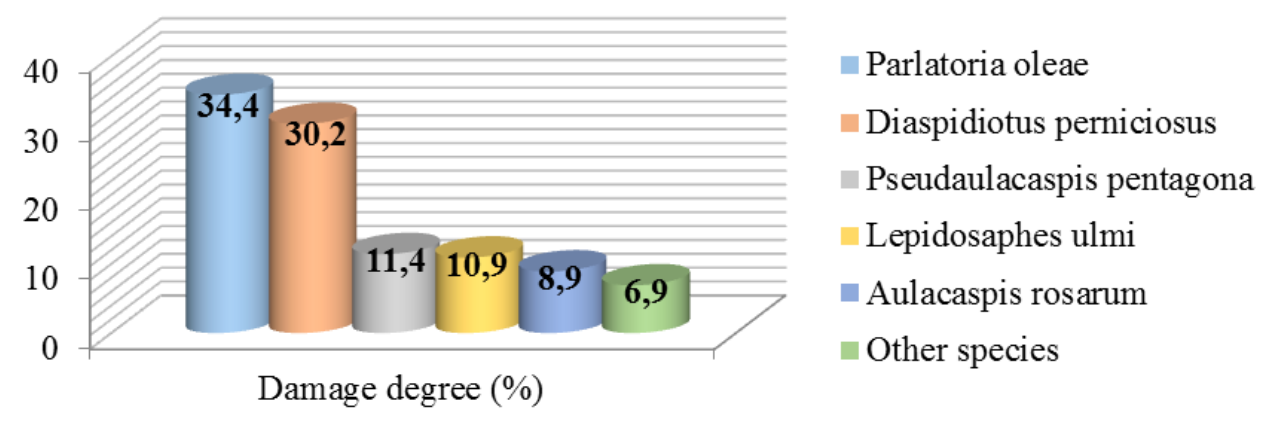

Fig. 2. Level of damage of apple trees in apple orchards (Tashkent province, 2018-2020)

Infestation of fruit trees with California scale (Diaspidiotus perniciosus Comst) affected pears and apples by $12.8 \%$, plums and apricots by $10.1 \%$, cherries and quinces by $10.9 \%$, peaches by $9.7 \%$, and cherries by a minimum of $8.6 \%$ (Figure 3 ).

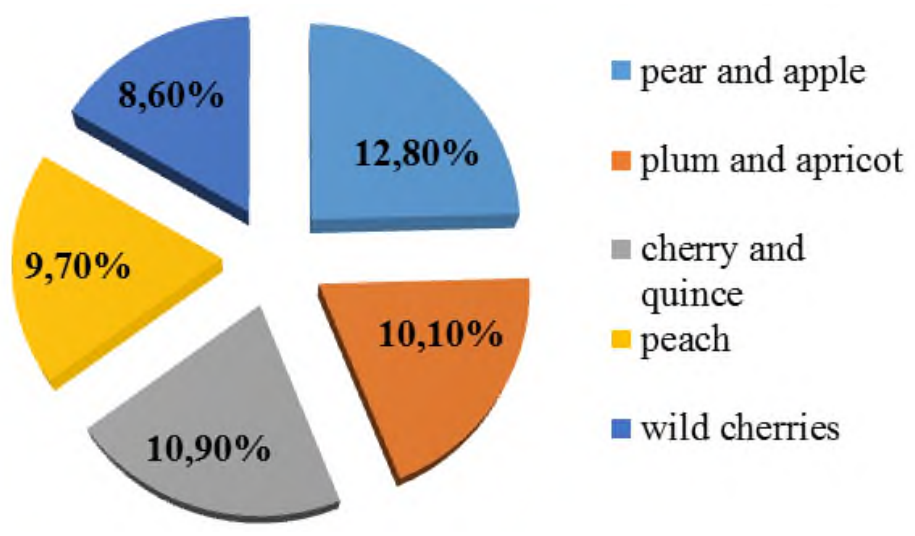

Fig. 3. Infestation of fruit trees with California scale (Tashkent province, 2018-2020). 


\section{Conclusion}

According to the taxonomic composition of the fauna of scales found in fruit and ornamental plants of Tashkent province, the number of generations in the family Diaspididae in the fauna is 18 (Diaspidseiotus, Diaspis, Dynaspidiotus, Unaspis, Shansiaspis, Salicicola, Parlatoria, Lepidosapis, Lepidosaphes, Lepidosaphes, Lepidosaphes Carulaspis, Rhizaspidiotus, and Pseudaulacaspis), and the number of species was 30 .

The number of species of the genus Chlidaspis, Prodiaspis, Mercetaspis, Carulaspis and Rhizaspidiotus is monotypic, the representatives of the genus Parlatoria and Chionaspis have 2 species and account for $13.3 \%$ of the total fauna, while Aonidia, Chlidaspis, Prodiaspis, Mercetaspis, Carulaspis and Rhizaspidiotus genus have 1 species, accounting for $46.7 \%$ of the total fauna.

Among the identified species, Diaspidseiotus transcaspiensis (Marlatt, 1908), Diaspis bromeliae (Kerner, 1778), Dynaspidiotus ephedrarum (Lindinger, 1912), Parlatoria ephedrae (Lindinger, 1911) were recorded for the first time for the scaleofauna of Tashkent province.

In apple orchards, the purple scale and California scale accounted for $34.4 \%$ of the total scale damage rate. California scale infestation of fruit trees affected $12.8 \%$ of pears and apples, $10.1 \%$ of plums and apricots, $10.9 \%$ of cherries and quinces, $9.7 \%$ of peaches, and at least $8.6 \%$ of cherries.

\section{References}

1. M. M. Harsur, S. Joshi, R. K. Pal, Oriental Insects 53(1), 104-111 (2019)

2. M. Moghaddam, G. W. Watson, Zootaxa 4907(1), 1-276 (2021)

3. N. Z. Elekcioğlu, M. Ölçülü, Bitki Koruma Bülteni 58(3), 131-139 (2018)

4. D. Ofgaa, G. Emana, K. G. Ruth, African Journal of Agricultural Research 13(31), 1598-1605 (2018)

5. J. Wei, Q. Zhao, W. Zhao, H. Zhang, PeerJ 6, e4832 (2018)

6. KH. Kimsanbaev, B. Murodov, U. Ortikov, O. Sulaymonov, J. Yakhyoev, Agroecological aspects of sustainable development, 91-93 (2019)

7. KH. Kimsanbaev, B. Murodov, U. Ortikov, A. Anorbaev, J. Yakhyoev, Actual problems of modern science 4(107), 176-178 (2019)

8. B. Murodov, U. Ortikov, J. Yakhyoev, Euroasian union of scientists 5(74), 39-40 (2020)

9. KH. Kimsanbaev, B. Murodov, U. Ortikov, O. Sulaymonov, J. Yakhyoev, International Journal of Research 6, 142-148 (2019)

10. KH. Kimsanbaev, B. Murodov, U. Ortikov, J. Yakhyoev, Journal of Agro Processing, 104-112 (2020)

11. J. Yakhyoyev, KH. Kimsanbayev, B. Murodov, B. Sulaymonov, The American Journal of Agriculture and Biomedical Engineering, 124-131 (2020)

12. P. Amouroux, D. Crochard, J. F. Germain, M. Correa, J. Ampuero, G. Groussier, T. Zaviezo, Scientific reports 7(1), 1-12 (2017) 
13. K. Erözmen, B. Yașar, Süleyman Demirel Üniversitesi Fen Bilimleri Enstitüsü Dergisi 22(1), 172-181 (2018)

14. M. Moghaddam, M. Abdollahipour, Y. Fathipour, In: Polyphagous Pests of Crops, 273-309 (2021)

15. T. M. Milek, M. Šimala, M. Bjeliš, M. Pintar, V. Markotić, Updated check list of scale insects (Hemiptera: Coccoidea) on olive trees in Croatia with special regard on Black araucaria scale-Lindingaspis rossi (Maskell 1891) 121, 91-97 (2017)

16. J. Yakhyoyev, KH. Kimsanbayev, The American Journal of Agriculture and Biomedical Engineering, 104-112 (2020) 